\section{IJ§ER}

ISSN: 2149-5939
International Journal of Social Sciences and Education Research

Online, http://dergipark.gov.tr/ijsser

Volume: 4(4), 2018

\title{
The unfounded mass burials of the so-called Armenian Genocide
}

\author{
Yurdagül Atun ${ }^{1} \quad$ Ata Atun $^{2}$
}

Submission date: 15 / 07 / 2018

Accepted date: $01 / 10 / 2018$

\begin{abstract}
According to some sources, The Armenian Genocide Appeals (the so-called Armenian Genocide or the Unfounded Armenian Claims) indicate that the Armenian deportation, which was carried out by the Ottoman State in Eastern Anatolia for internal security reasons from May to November 1915, was aimed at destroying the Armenian community in the region, Millions of Armenians are alleged to have been killed by this reason. In the early years of the First World War, the Ottoman State while fighting in many fronts with Allied Powers, the Armenians attacked the Ottoman army jointly with the Russian army in the region up to Central Anatolia in the East and rebelled in many cities. In order to overcome these rebellions, the Ottoman State held a joint meeting with the Armenian Patriarchs, especially the Armenian Members of the Tanzimat Parliament, and the leaders of the Armenian community, and informed them that the Ottoman State would take countermeasures if the Armenians continued to kill local Muslim people in Eastern Anatolia. On the basis of this notion, the Ottoman State in April 24, 1915 arrested 235 people who had organized the rebellions and closed down all the Armenian Committees and local organizations that supported and organized the rebellions. The Ottoman State promulgated the Temporary Law of Deportation, in 27 May 1915. Accordingly, it was decided some of the Armenians in Eastern Anatolia would be displaced to Syria, Lebanon and Iraq. According to the Armenians' claims, massacre and genocide were carried out under the deportation title and 1.5 million Armenians were killed. This article is about the mass graves of 1.5 million Armenians which would form the basis of the massacre allegations, the size, how and by whom they were dug, how the massacred Armenians buried and how the mass graves covered with soil. The paper is written to investigate whether there are mass graves or not.
\end{abstract}

Keywords: Ottoman, Armenian, Deportation, Mass grave, Genocide

\section{Introduction}

According to Halaçoğlu: "The Ottoman archives carry instructions to the effect that Armenians and their properties are not to be subject to any harm and ill treatments during their journeys, and protection for them is also to be provided. The Ottoman Ministerial Council decided on 30 May, 1915 to provide all necessary means including housing, tools and funding from the immigration policy in cluding medical check-ups. In addition, those who attacked Armenians during this transportation are the be arrested and punished under severe circumstances by the Court of Divan War." (Halaçoğlu, 2013).

Therefore, it is quite incompatible with the facts to claim that the Ottoman State, taking into account the lives, health and residence of the Armenians during their journey, committed a genocide under the referral of the Ottoman State, which issued a law ordering sick, elderly and children to be looked after. It is incompatible with logic as well as mathematical computation.

${ }^{1}$ Cyprus Science University, Department of Communications and Media, TRNC, yurdagulbeyoglu@hotmail.com ${ }^{2}$ Cyprus Science University, Department of Civil Engineering, TRNC, ata.atun@atun.com 
Atun, Y., Atun, A. (2018). The unfounded mass burials of the so-called Armenian Genocide. International Journal of Social Sciences and Education Research, 4(4), 571-579.

\section{Mathematical evaluation}

According to the Armenians' allegations, the so-called genocide was carried out within five and a half months from the end of May to the middle of November. It is not possible to actually claim that "Thousands of Armenians were forced to die freezing from the cold" as this can not be realized due to the climatic conditions within the period.

There is also a major calculation error in terms of the claims against the conduct of the Ottoman State that must be looked at more closely. Suffice to stay, if a total of one and a half million Armenians were killed during this so-called massacre or genocide, which began at the end of May and ended in the middle of November, the law enforcement officers, ordained by the Ottoman State on average, must systematically kill tens of thousands of people every day. If one decides to approach these claims optimistically, assuming that every single Armenian murdered is killed by a single bullet, 10,000 bullets must be spent each day and 1.5 million bullets in total. According to the Ballistic Table, a bullet weight of $7.65 \mathrm{~mm}$ is 6.5 grams on average (Ballistic Table, http://www.paganx.org/balistics.htm).

The total daily requirement of 10,000 bullets is $65 \mathrm{~kg}$, together with casings $85 \mathrm{~kg}$. Therefore, a total of 12.75 tons of bullets are required. Since these bullets can only be carried on the backs of animals in the mountains, this would be only possible with 2 donkeys or 2 camels and 4 people doing at least 2 shifts in order to carry the necessary daily bullets to the slaughter area. Also, in order to keep 10 thousand people under control and execute them, it is necessary to have a military unit or armed enforcement force available in the area.

We are talking about the past, and therefore must know that it is not possible that such deep pits cannot be dug without the aid of trucks, excavators and the technology of today. Since thousands of excavators and trucks cannot be used in the past, thousands of people are needed to dig the mass graves, and to throw the slaughtered into the pits, and to cover them again. A service team providing food, beverages, toilets, and bathing for these thousands of armed people who are supposed to have carried out the massacres or genocide must also be in the vicinity of the slaughter field to address the needs of the alleged murderers.

\section{Massacres and mass graves found in the world}

In 2018, five new mass graves were uncovered in the Arakan province of Myanmar, revealing the severity of the massacre against the Muslim population (Hurriyet, 2018). According to the Associated Press (AP) news agency, the discovery of at least 5 mass graves buried 400 unknowns in the $\mathrm{Gu}$ Da Pyin village of Buthidaung province, northern part of the province of Arakan province, has been confirmed (Atwood, 2018). According to Amor Mashovic, president of the DNA Center in Tuzla, “...When you include the year 2015, the number of public cemeteries in the country is 800 . I cannot believe that the war in which 32 thousand 152 people were "lost" to records is still not officially considered "genocide". In 1995, the mass graves of the corpses were buried with shovels and were seen by the American satellites. Some mass graves have 1200, some have 200 people..."

To sum up, Amor Mashovic declares that 32,152 people have been massacred and that these people have buried 800 mass graves that have been replaced three times (Masovic, 2015). According to the news of Yeni Safak Newspaper dated March 24, 2018; "110 ÖSO soldiers were 
Atun, Y., Atun, A. (2018). The unfounded mass burials of the so-called Armenian Genocide. International Journal of Social Sciences and Education Research, 4(4), 571-579.

killed by the PKK / PYD'deki in Syria in the empty square of the Hallubi village, mass graves were found near the dam." (Yeni Şafak, 2018).

According to Türkiye Newspaper's news on 24 April 2001; "Algeria (UAE) - The traces of the massacres carried out by the French during 1954-1962 in Algeria have still not disappeared. In the city of Tebessa, east of Algeria, there was a body of 300 Algerian fighters who were estimated to have been killed during the Algerian-French war between 1954 and 1962, the corpses were found during a water-pipe dig. The spokesman of the Ministry of War explained that the corpses belonged to the soldiers of the National Liberation Front and that there were traces of torture on their skeletons. It was stated that this mass grave was the largest mass grave in the last decade. " (Türkiye, 2001).

The news about the three different regions of genocide and mass graves in the world reveals that the mass graves buried after the massacres are revealed that investigations prove that no mass grave can be hidden, despite the fact that the burial sites have been changed three time, as is the case in Bosnia.

\section{Dimensions of the human body}

In order to be able to generalize calculations, it is necessary to take the average of the dimensions of the human body.

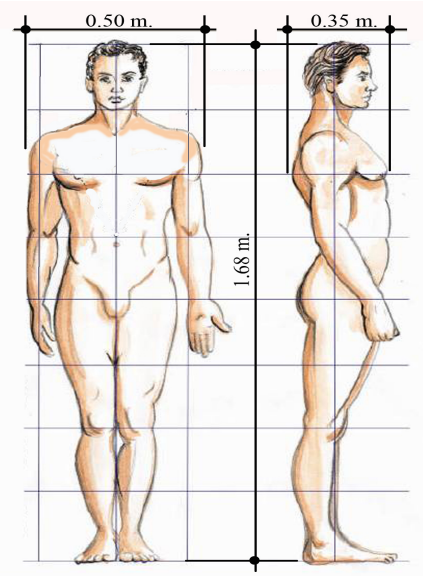

The average size of people living in Eastern Anatolia region:

Shoulder width: $0.50 \mathrm{~m}$.

Height: $1.68 \mathrm{~m}$.

Body thickness: $0.35 \mathrm{~m}$.

The body is covered horizontally Area: $0.84 \mathrm{~m}^{2}$

The volume produced horizontally by the body: $0.294 \mathrm{~m}^{3}$

According to unfounded Armenian allegations that 1,5 million Armenians were killed in five and a half months, the average number of people killed per day: 10,000 people. Assuming that three people were placed on top of a mass grave:

Man, in each horizontal row: 3334 people

The height of the volume created by three people on top of each other: $1.05 \mathrm{~m}$.

The minimum soil height that must be covered by 3 people: minimum $0.65 \mathrm{~m}$.

Total excavation depth: Minimum $1.05+0.65=1.70 \mathrm{~m}$.

Total excavation area: 3334 (one horizontal row human figure) x 0.84 (horizontal area of the body) $=2800 \mathrm{~m}^{2}$ Volume to be excavated: $1.70 \mathrm{~m}$. (Excavation depth) $\mathrm{x} 2,800 \mathrm{~m}^{2}$ (Total excavation area) $=4760 \mathrm{~m}^{3}$ 
Atun, Y., Atun, A. (2018). The unfounded mass burials of the so-called Armenian Genocide. International Journal of Social Sciences and Education Research, 4(4), 571-579.

\section{Size of football field}

Football field measurements are in the form of a rectangle. The width of the football field should be between 45 and 90 meters and the length between 90 and 120 meters. Regular football stadiums made in international standards are between 64 and 75 meters in size and between 105 and 120 meters in height. The average width of a football field is $50 \mathrm{~m}$ and the length is 100 m. the soccer field covers an area of about 5,000 sqm.
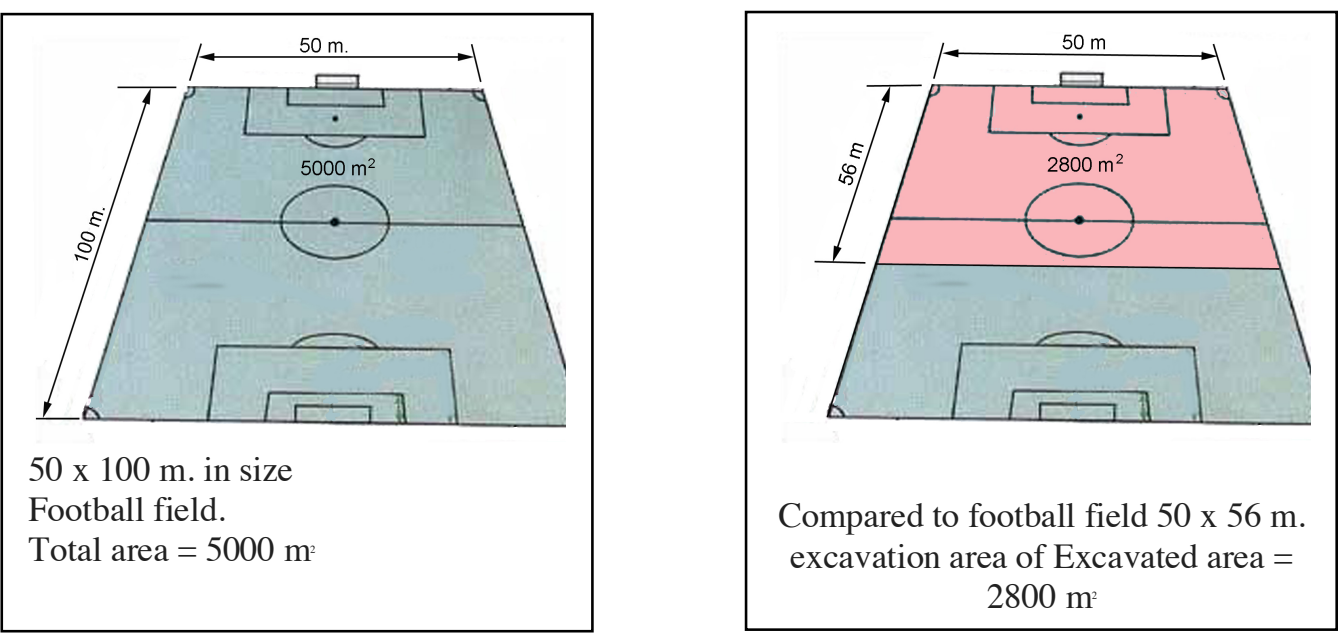

Since the area of the mass grave to be excavated must be at least $2800 \mathrm{~m}^{2}$, in terms of making comparisons this field is about $1 / 2$ football field or $50 \mathrm{~m}$. in width and $56 \mathrm{~m}$. It can be defined as a rectangle in its length.

\section{Excavator excavation capacity}

Today, with an excavator capacity of $0.75 \mathrm{~m}^{3}$ bucket capacity and 90 percent bucket capacity, an excavator is able to excavate only $258 \mathrm{~m}^{3}$ in one hour with easy, medium and medium difficulty. Such a scoop can excavate a $4760 \mathrm{~m}^{3}$ cavern at 18.5 hours without stopping and 22.5 hours with food and catering (Celal et al,).

\section{Manual excavation capacity}

According to calculations of King Fahd University of Petroleum and Minerals, the excavation capacity of 3 workers and the top head is $40 \mathrm{~m}^{2}$ per 16 hours or $2-4 \mathrm{~m}^{3} /$ hour according to soil structure. According to this finding, the average excavation capacity of a worker for 1 hour is 0.5 $\mathrm{m}^{3}$ (King Fahd, 2017). According to another source; the average amount of excavation that a person can do in a total of about 10 hours by working 2 hours per day for a 15-minute break and for a 45-minute break during lunch is about $4.0 \mathrm{~m}^{3}$. (Calin et al, 2003: $\mathrm{p}$ 201). According to this finding, the average excavation capacity of 1 hour is $0.4 \mathrm{~m}^{3}$.

According to the empirical findings of Goldenseal, 1 worker can excavate $1,308 \mathrm{~m}^{3}$ in 2.5 hours. (Goldenseal, 2017) According to this finding, the excavation capacity of one worker is $0.52 \mathrm{~m}^{3}$ per hour according to soil structure. When the average of these 3 differences are taken, the excavation capacity of 1 worker can be taken as $0.48 \mathrm{~m}^{3}$ per hour according to soil structure. According to the empirical findings of Goldenseal, a worker can emit 1,308 cubic meters of excavated soil in an excavation pit in 2.5 hours. According to this finding, the earth-throwing capacity of one worker is $0.52 \mathrm{~m} 3$ per hour according to the soil structure (Goldenseal, 2017). 
Atun, Y., Atun, A. (2018). The unfounded mass burials of the so-called Armenian Genocide. International Journal of Social Sciences and Education Research, 4(4), 571-579.

Another worker puts this land in a hand-held car with an average capacity of 1,308 cubic meters in 2.6 hours and pours back 10 meters away. According to this finding, the carrying capacity of one worker is $0.50 \mathrm{~m} 3$ per hour according to soil structure. (Goldenseal, 2017) According to these findings, on average 3 workers are required to excavate $0.5 \mathrm{~m} 3$ of soil in 1 hour, to be thrown out of the shovel and to be taken out of the buried area.

Minimum mass grave area required to bury 10,000 people: $2800 \mathrm{~m}^{2}$ Minimum excavation depth: $1.70 \mathrm{~m}$. Soil volume to be excavated: $2800 \mathrm{~m} 2 \times 1.70 \mathrm{~m}=4760 \mathrm{~m}^{3} .4760 \mathrm{~m}^{3}$ Number of persons required to be able to perform soil excavation in maximum 10 hours: $4760 \mathrm{~m}^{3} \div 10$ hours $\div 0.48 \mathrm{~m}^{3} /$ hour $/$ worker $=992$ workers (Digging the pit). Amount of soil excavated in 1 hour $=$ $4760 \mathrm{~m}^{3} \div 10$ hours $=476 \mathrm{~m}^{3}$. The number of workers required to discharge $476 \mathrm{~m}^{3}$ of land excavated in 1 hour; $476 \mathrm{~m}^{3} \div 0.52=916$ workers (landing). The number of workers required to move one third of the land $(1.70-1.05=0.65 \mathrm{~m})$ out of the excavation pit in one hour to outside the excavation area: One third of the soil mined in one hour $=476 \mathrm{~m}^{3} \div 3=159 \mathrm{~m}^{3}$. Number of workers required to remove $159 \mathrm{~m} 3$ of soil from the excavation area: $159 \mathrm{~m} 3 \div 0.5 \mathrm{~m} 3=318$ workers (carrying the surplus of the disposable soil out of the field)

Movement of the bodies of the slaughtered people to the burial site to be thrown immediately to the pits without waiting for it to finish, 3 rows above and $65 \mathrm{~cm}$ above them. the number of additional people required for each $1 \mathrm{~m} 2$ excavation area to be covered with soil is 2 .

Excavation area $=2800 \mathrm{~m}^{2}$

Area to be excavated per 1 hour over 10 hours $=2800 \mathrm{~m}^{2} \div 10$ hours $=280 \mathrm{~m}^{2}$

$280 \mathrm{~m}^{2}$ Number of additional people required for burial in the excavation area:

$280 \mathrm{~m}^{2} \times 2$ people $=560$ people (burial and covering)

The number of workers required for excavation (992 persons), landing out (916 persons), carrying out the land (318), burial and covering (560 persons) within 1 day with a working time of 10 hours: $992+916+318+560=2786$ people. The minimum total number of workers required for 5 days shifts and 2 teams per day is estimated to be $2786 \times 2=5572$ workers, since it is not possible for the mentioned workers to work 10 hours each day without interruption for 150 days.

The number of people required to meet the food, drinking water, rest, sleep, cigarette, disease, treatment, first aid, wash water and toilet needs of 5,572 people working five hours a day, two shifts, this being the most optimistic and minimum estimate;

Delivery of food: 25 people

Travel kitchen and dishwashing: 50 people

Drinking water and washing water supply: 45 people and 20 water transport vehicles, 40 cows and caring.

Establishment and deterioration of the traveling dormitory: 50 people

Expedition hospital and treatment hospital: 15 people

Total service staff: 185 people

Even assuming that tens of thousands of captured prisoners are left hungry and thirsty, if there are no prisoners surrounded by barbed wire around the Nazis, and the prisoners are confiscated outdoors, the minimum number of soldiers required to prevent such prisoners from escaping and revolt is at least 2500. Systematically slaughtering 10 thousand people a day, so that 1.5 million people can be slaughtered in the timeframe of five and a half months, the opening of the pits in the size $50 \times 56 \mathrm{~m}$., the burial of the slaughtered and the covering of them. A total of at least 8257 
Atun, Y., Atun, A. (2018). The unfounded mass burials of the so-called Armenian Genocide. International Journal of Social Sciences and Education Research, 4(4), 571-579.

people are required to perform these operations. (5572 workers +185 kitchens and supply +2500 soldiers).

In addition to human power, there are approximately 1,000 digging tools (992 people for excavation), 1000 shovels (916 people for throwing out land), 200 shovels (318 people for carrying out land), and 600 shovels for burial and 560 people to cover it), in total: 1000 pieces of digging and 1800 shovels are required together with the backups. 1000 pieces of digging and 1800 shovels are required together with the backups.

\section{Armenian population in Anatolia in 1915}

The archives have censuses from 1882 to 1915. Instead of Ottoman documents, the population declarations given by the French, British, Germans, Americans and the missionaries there, and especially the Armenian Patriarch to the Ottoman Empire in relation to taxes, helped the determination of the Armenian population in Eastern Anatolia in 1915.

\section{The Armenian population declared by the Armenian Patriarch N. Varjabedian in 1881}

According to the Armenian Patriarchate, the figures of Catholic and Protestant Armenians in six provinces are explained in 1881 (the column A) across to the explanation made in 1882 (the column B) as follows (Atun, 2013);

Table 1. The figures of Catholic and Protestant Armenians in six provinces are explained in 1881 and 1882

\begin{tabular}{|l|c|c|}
\hline & A & B \\
\hline State & Year $\mathbf{1 8 8 1}$ & Year 1882 \\
\hline Erzurum & 128,478 & 280,000 \\
\hline Van & 133,859 & 400,000 \\
\hline Bitlis & 130,460 & 250,000 \\
\hline Diyarbekir & - & - \\
\hline Elaziz & 107,059 & 270,000 \\
\hline Sivas & 243,515 & 280,000 \\
\hline Total & 743,371 & $1,630,371$ \\
\hline & According to the Armenian \\
& Patriarchate in 1881 & $\begin{array}{c}\text { According to the explana- } \\
\text { tion made in 1882 }\end{array}$ \\
\hline
\end{tabular}

When the lists are placed side by side, it is seen that the population increase within a year is 887 thousand people, 120 percent, it appears that the increase is not normal and quite misleading. Colonel Henry Trotter, the British Embassy specialist concerning population reports noticed inconsistent figures in the explanation of Patriarch and made a report. On February 15, 1882, the number of Armenians residing in the regions of Erzurum and Van was 372,500 and Nasuri was 85,000 (Atun, 2013).

\section{Other official documents and explanations about the Armenian population in Anatolia}

The total number of the population living in Erzurum, Van, Bitlis, Harput, Diyarbakır and Sivas regions is 2,615,000 - 666,000 Muslims and 1,018,000 Armenian population in a 1912 study by Marcel Leart (Atun, 2013). In his book "Armenia On The Road To Independence", Richard Hovannisian explains that the population of Armenians living in the borders of the Ottoman State in 1914 is between one and two million, including Istanbul. In his book "Histoire de l'Armenie", Hrant Pasdermadjian explains that 2,100,000 Armenians lived in 1914, including Istanbul, within 
Atun, Y., Atun, A. (2018). The unfounded mass burials of the so-called Armenian Genocide. International Journal of Social Sciences and Education Research, 4(4), 571-579.

the borders of the Ottoman Empire, while the world had an Armenian population of 4,100,000. The number of Armenians living in Anatolia as of that date is 1,400,000 according to the content of the memorandum signed by A. Aharonian and Boghos Nubar on February 12, 1919 and submitted to the Paris Peace Conference by the Armenian Delegation (Atun, 2013).

The number of Armenians living in Anatolia is about 1,400,000, according to the content presented by the Greek Prime Minister Venizelos at the Paris Peace Conference on 12 February 1919 (Atun, 2013). Near East Relief Report on Armenians living in Syria in 1921: (Near East Relief Report). According to the report, after the F. Boullion Agreement signed with the Government of Ankara, the British-French occupations subsequently returned to the 300,000 Armenian Cilicia region and emigrated from the region in 1921. The report clearly states that between 200,000 and 300,000 Armenians are alive in the Syrian territory and that they want humanitarian assistance (Atun, 2013).

Near East Relief Report on Armenians living in Armenia in 1921: (Near East Relief Report) The report says that the number of Armenians living in Armenia in the Caucasus in 1921 was one million and half of them $(500,000)$ applied to the Aid Group for help (Atun, 2013). According to the US Senate's Resolution 266 of 22 April 1922, the number of Armenians living in Anatolia, Syria and Russia as of December 31, 1921 was 1,414,000 and no mention of genocide by any word, meaning or implication (Atun, 2013).

The total population of Armenians living in the world according to the contents of the Proof of Entitlement 1-8-58, a US government document signed by US Secretary of State W. R. Anderson in 1922, was 3,004,000. And 817,873 of them have migrated from Anatolia and 281,000 of them still live in Anatolia (Atun, 2013). 760,000 Armenians were living in the Ottoman territories according to the content of Andiç on 2 February 1923 presented to the Lausanne Peace Conference in 1923 (Atun, 2013). According to the information given by Şükrü Server Aya in the conclusion of the US Senate's review of the "Near East Assistance Report" dated December 31, 1929, the number of Armenians alive in history is 1,300,000 and the number of Armenians who died is incredibly low. The number of Armenians who die as a result of hunger, poverty, illness and regional conflicts is at most 300,000 if the official report of the US Senate is trusted (Atun, 2013 \& Aya, 2013).

\section{Conclusion}

According to the records in the Ottoman archives, the death was not found in the deportation records starting in May of 1915, to November. The Report of the Near East Assistance Group, created by the US Government, does not refer to the deportation as a massacre or genocide (Atun, 2013 \& Aya, 2013; http://armenians-1915.blogspot.com/2008/02/2335-free-e-book-near-east-relief.html). If one and a half million $(1,500,000)$ Armenians were killed within the five-month period of migration as the Armenians claimed, an average of ten thousand $(10,000)$ people a day should be killed by a simple mathematical calculation. According to this average, at least 150, $2800 \mathrm{~m} 2$ in size, about $50 \times 56 \mathrm{~m}$. is necessary as a mass grave in its dimensions to be found.

According to the most basic principle of law, in order for a murder claim to be prosecuted in court, the body of the person killed must also be found and presented to the court as proof (David, 2003, 817). Despite the fact that the mass graves of 8 thousand Bosnians, which were slaughtered by the Serbs mercilessly and the location changed 3 times, were found, some people doubt the alleged Armenian genocide allegations as they have not been revealed. 
Atun, Y., Atun, A. (2018). The unfounded mass burials of the so-called Armenian Genocide. International Journal of Social Sciences and Education Research, 4(4), 571-579.

The fact that none of the 8,257 people involved in such a massacre or genocide have not opened their mouths or and that no one has even been able to show a mass grave involving people killed in the alleged genocide, casts a shadow over the claims of genocide and undermines its credibility. When the reports on Armenians living in Anatolia, Syria, Iraq and Armenia in 1915 were examined, it is seen that the number of Armenians ranged from 600 hundred to 1 million 700 thousand. If one and a half million Armenians were slaughtered in 1915 as it was alleged, as in the reports published by the US Senate after the war, the number of Armenians living in Anatolia, Syria and Russia in 1923 could not be 1,414,000 and the number of Armenians migrating to USA and Europe could not be 817,873 .

These mathematical calculations and population censuses made in various years, given by the French, British, Germans, Americans and the missionaries there, especially the Armenian Patriarch, to the Ottoman Empire every year, and especially after the First World War reveal that the Armenian Genocide allegation is met with doubt, is groundless, and unfounded.

\section{References}

Atun, A. (2013). Armenian Population In Eastern Anatolia Around 1915.Academic Research International, Retrieved from: http://jml2012.indexcopernicus.com/abstract.php?icid=1058355\&id_lang=3

Atun, A. (2016). Armenian Population in Eastern Anatolia between Years 1878-1915. Retrieved from: http://jml2012.indexcopernicus.com/abstract.php?icid=1048495\&id_lang=3

Atun, A. (2013). Armenian Population In Eastern Anatolia Around 1915: A Brief History Of Armenian Hoaxes. Asian Journal Social Sciences \& Humanities, Retrieved from: http://jml2012.indexcopernicus.com/abstract.php?icid $=1056159 \&$ id_lang $=3$

Atwood, H. (2018). AP finds evidence of mass graves, systematic killings in Myanmar. AP, February 5, 2018. Retrieved from: https://www.lionsroar.com/ap-finds-evidence-of-mass-graves-systemic-massacre-of-rohingya-in-myanmar/

Aya, Ş. S. (2013) Review of Near East Relief Report 31 Dec 1921, US Senate, 67th Congress 2nd Edition, Document No. 192, Washington, Government printing Office, 1922 Retrieved from:

Goldenseal Reference Manual (2017). Goldenseal Unit Costs. Soil Removal Cost, Difficult Hand Loading. USA. Retrieved from: https://www.turtlesoft.com/Construction-Costs/Excavation/Remove_Soil_Hand_Hard.htm

Halaçoğlu, Y. (2015). Sürgünden Soykırıma Ermeni İddiaları. İstanbul: Babıali Kültür yayınları.

Hovanissian, R. (1963). Armenia On The Road To Independence, Los Angeles, s.9

http://armenians-1915.blogspot.com/2008/02/2335-free-e-book-near-east-relief.html

Hurriyet, (2018). Retrieved from: http://www.hurriyet.com.tr/dunya/arakanda-5-yeni-toplu-mezarbulundu-40728105.

Karpuz, C., Paşamehmetoğlu, A. G., Müftüoğlu. Y. (2018) Hidrolik Ekskavatör Performanslarıyım Kazılabilirlik Tayini. Retrieved from: http://www.maden.org.tr/resimler/ekler/b5c8441a8ff8e15_ek.pdf

King Fahd University (2017). Pricing Excavation \& Backfill. King Fahd University of Petroleum and Minerals, Saudi Arabia. Retrieved from: http://faculty.kfupm.edu.sa/CEM/alkhalil/PDF_CEM_511/Pricing\%20Sitework.pdf

Masoviç, Amor. (24.12. 2015). Bosna Hersekteki Soykırım unutulmaz. 15 April 2018 Retrieved from: https://www.bosnahersek.ba/bosna-hersekteki-soykirim-unutulmaz/

Moran, D. A. (2003). In Defense of the Corpus Delicti Rule. Detroit: Wayne State University Law School, Detroit, Michigan. Ohio State Law Journal. Vol. 64 no. 3 (2003). 817-854

Pastermadjian, Hrant. (1949). Histoire de l'Armenie, Paris, 1949, 2.nd Ed. Douredjián, 1987, s.374 
Atun, Y., Atun, A. (2018). The unfounded mass burials of the so-called Armenian Genocide. International Journal of Social Sciences and Education Research, 4(4), 571-579.

Popescu, C. M., Ovararin, K. P. N. (2003). Estimating Building Costs, New York: Marcel Dekker Inc.

Slumber, J. (2011). Hand Excavation Productivity. Contractor Talk. Retrieved from: http://www.contractortalk.com/f62/hand-excavation-productivity-108557/

TASAM (2011). Tarihi Gerçekler Işı̆̆ında Ermeni İddiaları. İstanbul: Türk Asya Stratejik Araştırmalar Merkezi.

Türkiye Gazetesi (2001). Cezayir'de Fransızlar'a ait bir toplu mezar daha. İstanbul: Türkiye Gazetesi Basımevi. 15 April 2018 Retrieved from: http://m.turkiyegazetesi.com.tr/Genel/a106895.aspx

Yeni Şafak Gazetesi (2018). PKK/PYD'nin şehit ettiği ÖSO'lulara ait toplu mezar bulundu. İstanbul: Yeni Şafak basımevi, 24 March 2018 Retrieved from: https://www.yenisafak.com/video-galeri/dunya/pkkpydnin-sehit-ettigi-110-osolunun-gomuldugu-toplu-mezar-bulundu-2175809 